\title{
THE IMPLEMENTATION OF LAW ON THE PROTECTION OF WITNESSES AND VICTIMS FOR THE LAW EXISTENCE OF PEOPLE IN GORONTALO CITY
}

\author{
Weny Almoravid Dungga \\ Study Program of Law, Faculty of Law, State University of Gorontalo, Gorontalo, Indonesia \\ *Corresponding Author: tinekewolok73@gmail.com
}

\begin{abstract}
The people's need of legal certainty is the responsibility of all parties to make it happen. Various cases raised in society require the law enforcement agencies to follow up and protect the witnesses and victims. Gorontalo city is inseparable with some legal cases taken place in urban communities that require contributions from law enforcement agencies, including universities. This study focuses on the implementation of law on the protection of witnesses and victims for the law existence to people in Gorontalo city that employed normative juridical method in which it is a law study aimed at finding out the norms and "das Sollen". The result reveals that the implementation of law on the protection of witnesses and victims to people in Gorontalo city has not been effectively applied as resulted from the empirical factual review. Further, there are five important aspects that determine the existence of witness and victim protection agency, including 1) laws, 2) the witnesses' and victims' mental attitude, 3) professional law enforcement officers, 4) community control, 5) electronic media.
\end{abstract}

Keywords: Protection, Witnesses, Victims

\section{INTRODUCTION}

Public appreciation of law enforcement efforts in this country is generally experiencing a point of degradation that is very apprehensive to all parties. This is evidenced by some critics and strikes for both the executive and the legislative parties, and it is even starting to propagate to the law enforcement officers who are considered failing to guard the law in people's life.

A gradual and definite process is necessary for implementing the law in society. Building and actualizing the law in people's life will certainly encounter different challenges caused by internal and external factors of the people themselves. Basically, people should be able to accept the legal certainty in order to create a divine law. Therefore, laws and people's interests must be balanced which means that laws are created to protect people's interest itself.

In order to enforce judicial legal regulations, an agency that is capable of functioning continually is required to accommodate plenty of complaints, problems, and demands from the society. The law number 13 of 2006 on the protection of the witnesses and victims is expected to manage the inequities that occur these days so that it can provide the protection assurance towards the witnesses and victims. Gorontalo city as the capital city of the Province continues to its development. Nevertheless, this condition is also followed by the level of law violations taken place in Gorontalo City. Based on the preliminary data, the level of law violations in Gorontalo City is presented in the following table:

Table 1. Number of Cases in Gorontalo City

\begin{tabular}{|c|c|c|c|c|c|c|c|}
\hline \multirow[t]{2}{*}{ No } & \multirow{2}{*}{ Case } & \multicolumn{5}{|c|}{ YEAR } & \multirow{2}{*}{$\begin{array}{c}\text { Informati } \\
\text { on }\end{array}$} \\
\hline & & 2012 & 2013 & 2014 & 2015 & 2016 & \\
\hline 1 & Maltreatment & 68 & 82 & 29 & 51 & 82 & \\
\hline 2 & Security & 0 & 1 & 1 & 1 & 4 & \\
\hline 3 & Trafic Accident & 115 & 113 & 101 & 115 & 127 & \\
\hline 4 & Domestic Violence & 16 & 16 & 18 & 7 & 31 & \\
\hline 5 & Motorcycle Theft & 37 & 95 & 78 & 60 & 72 & \\
\hline 6 & Rape & 0 & 3 & 2 & 4 & 0 & \\
\hline 7 & Fornication & 2 & 5 & 1 & 0 & 7 & \\
\hline 8 & Murder & 0 & 0 & 2 & 3 & 1 & \\
\hline
\end{tabular}

Source: Resort Police of Gorontalo City, 2017 
The data show the number of criminal cases in Gorontalo city that need a law effort such as the protection of the witnesses and victims. The existence of laws governing the protection of witnesses and victims is an indispensable thing for those who are seeking justice. For that reason, the researcher is conducting a comprehensive study on "the Implementation of Law on the Protection for Witnesses and Victims for the Law Existence of People in Gorontalo City".

\section{METHOD}

According to M.S.W.Sumardjono (2001), normative law research emphasizes on the aspect of abstraction. The study on the Implementation of Law on the Protection of Witnesses and Victims for the Law Existence of People in Gorontalo City is a normative juridical study aimed at finding out the norms and das Sollen. The first step done in this study was a library research, and then completed the data of the library research by conducting a field research (S.Mertokusumo, 1996). Before analyzing the data, the primary data from interview and secondary data obtained by the documents about the protection of witnesses and victims were organized. Those data were then classified and written systematically and consistently to make it easier to be analyzed. The data used in this study were descriptive analysis so that it can get a comprehensive description of the rules regarding the focus of the problem. In normative law research that utilizes secondary data, this is a descriptive or explorative descriptive study that covers qualitative analysis (M.S.W.Sumardjono, 2001).

\section{FINDINGS AND DISCUSSION}

\subsection{The Implementation of Law on the Protection of Witnesses and Victims for the Law Existence of People in Gorontalo City}

Several experts have placed a court as the honorable institution. R. Dworkin (1986) states that the courts are the capital of law's empire. The unavailability of a legal provision by the judiciary will weaken the national resilience. Some legislation is strengthened for the law enforcement officers to implement and provide legal certainty in every case settlement. The Law on The Protection for The Witnesses is a mandate from the MPR Decree Number VII / 2001 on Recommendations of the Policy Direction on the Eradication and Prevention of Corruption (KKN). Widodo Supriyadi (2006) notes that in the overseas witness protection practice, the protection is provided until the criminal justice process is completed even up to the witnesses' lifetime. Law Number 13 of 2006 on Witness and Victim Protection Agency already governs the protection that must be given to witnesses and victims. However, looking at the provisions that exist in the law is still general; it should be more detailed in order to facilitate its implementation. Besides, the protection for witnesses and victims requires the role of law enforcement agencies. This agency is playing a vital role in implementing the things governed by the laws. This is in line with Soerjono Soekanto (1986) who confirms that the agency's role is based on the meaning of the agency as the set of norms from all levels that revolves around the basic needs in people's life.

Viewed by the standpoint of laws, the position of the witnesses and the victims is in a weak position. The Criminal Code, for example, even threatens with criminal sanctions if the witness does not come when the law enforcement officers ask him to give information. If we try to compare the legal protection for the witnesses on the one hand and the suspects on the other, we may come to the idea that the suspects' rights are given due to their weak position, so that it comes to the Abuse of Power. Meanwhile, the witness and the victim are considered no longer need to have rights that provide protection for them in the judicial process since they have been represented by the country acting as the executor of the justice process. The establishment of the law enforcement process has something to do with the lawmaking process. This is argued by one of the law scholar; Romly Atmasasmitha (2001), who explains that the Law Enforcement Process and Law Making Process are related to each other because an aspirational and credible lawmaking process can influence a good and responsible law enforcement process. Truthfully, if we look at the reality, the witnesses' condition is not much different from the suspect's/defendant's condition in which they both need protection because of these following aspects:

1. For the lay witness, giving a statement is not an easy matter;

2. If the information is not accurate there will be a criminal penalty for the witness because of his perjury;

3. The information may enable the witness to face threats, terror, and intimidation from the aggrieved party;

4. Providing information is wasting time and money;

5. Law enforcement officers often treat the witnesses like a suspect/defendant.

The protection for the witnesses and victims should be the provision of a set of rights that can be used in the criminal justice process. This protection is a kind of appreciation for their contribution to this process. The protection for the witnesses and victims should be created by the law enforcement agencies in which Kadafi (2002) has stated that this is implemented by providing law of education to the society. The data obtained from Police Resort in Gorontalo City, for example, show that there is a case of defamation of the Gorontalo City Council Officials over the use of fake certificates in which the witness was initially treated well as a witness. However, he immediately becomes the suspect without going through the procedure checks as regulated by the laws. The strong political pressure causes that the witness is mistreated. Moreover, he is also directly subject to detention without 
prior notice as provided in the Criminal Procedure Code. This is apparently in contrast with the legal procedure that we hold especially the Criminal Procedure Code.

Further, it is similar to the level of the investigation at the prosecutor's office. The data obtained by the researcher in the corruption case in National Education Agency reveal that the one who was previously a witness becoming a suspect and subsequently imprisoned due to the political interest. In fact, the initial investigation on the news event conducted by the police has determined the suspect. Even the suspect that has already been specified in the Official Report will not run away and has provided an assurance. Similarly, this kind of situation also takes place at Gorontalo District Court. A person as an expert witness in the corruption case in Gorontalo City Council notes that sometimes the judge cannot act objectively against the presence of the witness. This is evidenced at the time of the case investigation; the judge only takes into account the first expert witness's opinion that refers to the ignorance of the next expert witness's information. In procedural law, it is very contradictory since one expert witness's opinion may complete the opinion of another expert witness. Meanwhile, the other law such as the Criminal Procedure Code does not have specific, detailed and complete regulation concerning the witnesses' and victims' rights in the criminal justice process.

However, it does not mean that our laws do not have such regulations. The existence of rights in the laws cannot certainly guarantee the witnesses and victims to get the real protection. There have been many examples of how difficult it is to implement the regulation of the laws, especially with regard to the granting of rights. The initiative to formulate the law on the protection for witnesses and victims is based on the difficulty of revealing the corruption cases. It is also motivated by the awareness that every witness in any criminal cases is generally in the same situation. Therefore, the witnesses and victims should be granted the following rights:

1. The right to the reimbursement of transportation costs;

2. The right to get the law advice;

3. The right to be informed about the case progress;

4. The right to be informed about the court ruling;

5. The right to be informed when a convict is given (if imprisoned).

For the victim-witnesses, some special rights should be granted, including:

1. The right to get attention to the opinions given at every stage of the investigation;

2. The right to the restitution from the offender;

3. The right not to be approached by the offender or his group within a certain radius in specific injunction orders.

For the victim of violent crime that causes severe physical or psychological suffering, it is possible to obtain rights of:

1. Medical assistance;

2. Psychological consultative assistance

3. The right to the compensation from the country.

\subsection{The Important aspects that determine the Existence of Witness and Victim Protection Agency}

It cannot be denied that the focus of attention in a judicial process is the person who violates the law, including the suspect/defendant and also the witness of criminal justice. The existence of the witness protection agency is strongly influenced by some things such as:

\subsection{Laws}

The law on the protection of the witnesses and victims is already regulated, yet it is still challenging to be implemented. This is caused by the unavailability of an agency that can realize a protection for the witnesses and victims as mandated by the law on the protection itself. The government has not been able to determine the members who will carry out the duties and obligations of the witness and victim protection agency, thereby it is argued that the government is paying little attention to the substance of the law article 1 that mandate the government to immediately establish a witness protection agency once the witness protection law is legalized. Similarly, the law on the protection for the witnesses and victims is incomplete as there is no limit to this law which refers to criminal cases, and the other cases such as witnesses in military, civil, and country's administrative cases are not included.

\subsection{The Witnesses' and Victims' Mental Attitude}

The presence of witnesses in a case is necessary. The importance of witness's status in the criminal justice process has begun since the beginning of the criminal justice process. It must be admitted that the disclosure of cases of the law violations is largely based on the information from the society. Same as the next process at the prosecutor's office and court, the witness's statement as the main evidence has become the judge's reference in deciding whether or not the defendant is breaking the law. Given the great risks to be faced by the community in reporting or witnessing a criminal act, it is reasonable that the witness is offered a legal protection from various threats that arise 
in the future. Handling all those criminal acts should not be impeded due to the unavailability of the witnesses' safety assurance. Thus, the availability of witness protection mechanisms is very meaningful to expose all kinds of crime. The goal is to guarantee the truth as well as to meet the sense of justice for all parties, including the witnesses and victims. The right to freely give the information and opinion is one of the most important and indispensable rights a suspect, defendant, and witness must possess. On that ground, the right to provide information to both law enforcement officers and to legal counsel should not have any obstacles such as pressure, coercion, influence, or technological failure in the process of presenting the information. Without an adequate legal safeguard, it will affect the witnesses' and victims' attitude and mentality in providing the information.

\subsection{Professional Law Enforcement Officers}

The position of judges, prosecutors, police, and lawyers as the legal professions in actualizing the law enforcement is significant in carrying out the legal process. As the part of law enforcement, it is necessary to balance the status and the role of each profession, so that the mechanism will run well. Their independence is also required in order to be the part of the judicial system control. As the representative of a country that has received a mandate from the people, the law enforcement officers are argued to have the stronger position than the offenders. This situation can cause a concern on the arbitrariness of law enforcement officers in using their authority.

A major challenge that continues to follow the development of the law enforcement profession in Indonesia is the effort to place an appropriate role in its interaction with the society and the country (a reciprocal relationship). The society will put a trust over the public promises declared by the law enforcement officers in seeking the truth, justice, and legal certainty.

\subsection{Community Control}

The people's role in monitoring the law enforcement is very urgent to realize the protection of human rights. In addition, their role in overseeing this agency is crucial to enhance the judicial credibility to be able to produce quality decisions and reflect the legal certainty, justice, and benefit. By providing legal protection for the witnesses, the people's participation in giving the information about the criminal acts will be higher. This will certainly accelerate the settlement of crimes that have been difficult due to the lack of evidence.

It is essential to strengthen the community certainty in the process of taking and monitoring the protection of the witnesses and victims as well as encouraging the people's initiatives to expose all manipulations. Therefore, every person who has participated in the protection of the witnesses and victims must be rewarded according to their role. This is applied in order to increase their participation in the criminal report.

The society plays a vital role in the protection of witnesses and victims. Social interests that occur in daily life, especially to the witnesses and victims, require the role of community control. By this control, it is expected that the negative behavior or treatment towards the witnesses and victims will be reduced or even be resolved.

\subsection{Electronic Media}

The witness's condition is not much different from the suspect's / defendant's condition because they both need protection. This is caused by several things, including:

1. For the lay witness, giving a statement is not an easy matter;

2. If the information is not accurate, there will be a criminal penalty for the witness because of his perjury;

3. The information may enable the witness to face threats, terror, and intimidation from the aggrieved party;

4. Providing information is wasting time and money;

5. Law enforcement officers often treat the witnesses like a suspect/defendant.

Handling all those criminal acts should not be impeded due to the unavailability of the witnesses' safety assurance. Thus, the availability of witness protection mechanisms is significant to expose all kinds of crime. The goal is to guarantee the truth as well as to meet the sense of justice for all parties, including the witnesses and victims.It is undeniable that the media is playing a significant role in disseminating the mistreatment cases towards the witnesses and victims by the law enforcement officers. Nevertheless, the news media is sometimes inappropriate and less concerned with the witnesses' and victims' interests.

The media must play a key role in preventing the mistreatment towards the witnesses and victims. As a great power capable of forming public opinion, the media should be able to create more responsible and educative programs and reports in order to reach the promotive and preventive efforts. The other media's roles are to mobilize public opinion, advocate for policy and make it a political agenda, and provide the education for the society in order to raise public awareness on the importance of witness and victim protection issue and its prevention efforts. Based on the explanation, the important aspects that determine the existence of the protection for the witnesses and victims are shown in below figure. 
Figure 1. The Important Aspects that Determine the Law Existence in Gorontalo City

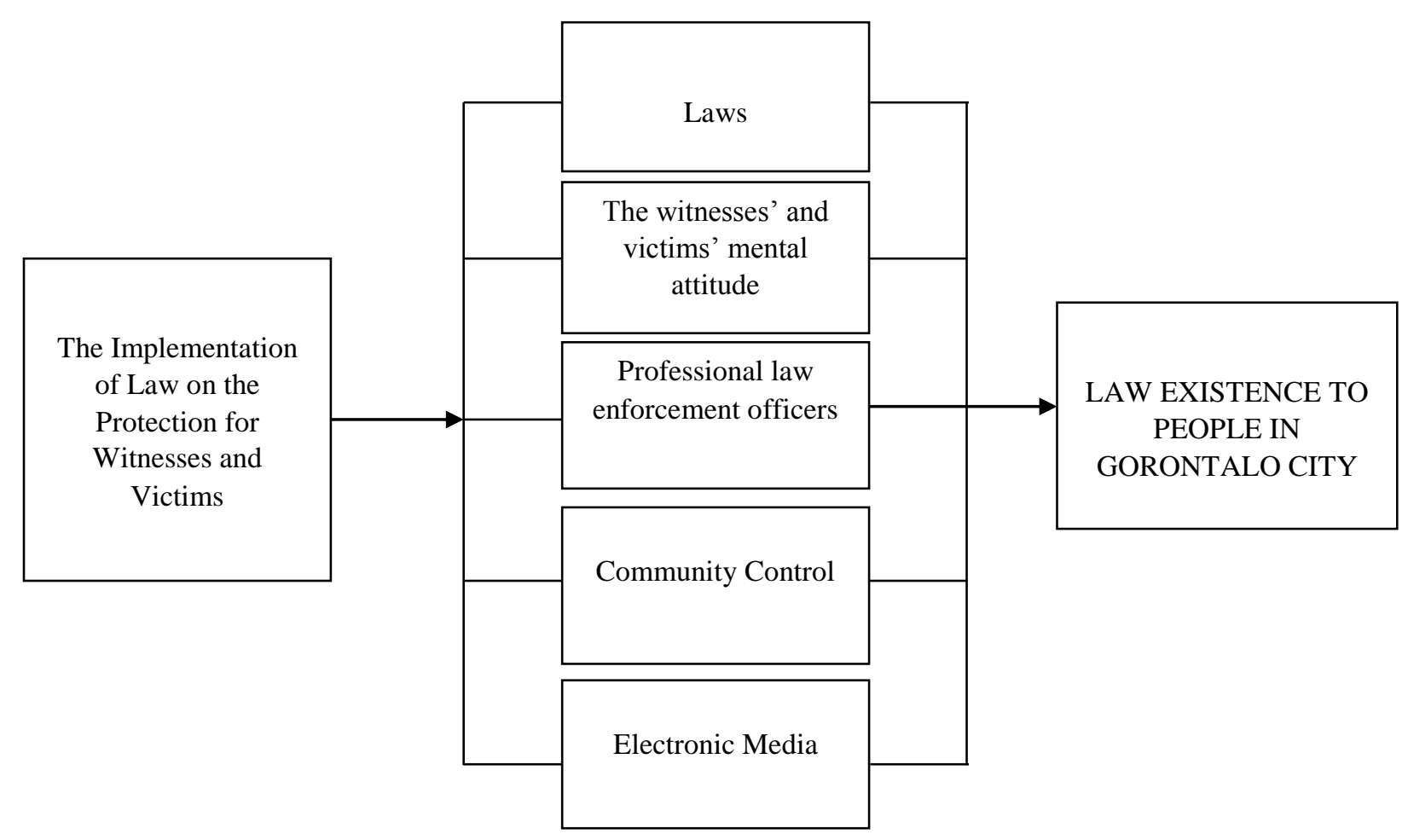

Source: The Result of Field Research, 2017

\section{CONCLUSIONS}

Some conclusions are drawn based on the findings and discussion, including:

1) The protection for the witnesses and victims has not been optimally implemented due to the unavailability of the implementation rules regarding the protection as well as the unavailability of the independent agency that implement the law on the protection for the witnesses and victims;

2) Improving the facilities and infrastructures, the quality of education, the quality and the performance of law enforcement officers in order to guarantee the protection for the witnesses and victims;

3) Establishing a protection agency in the province, city or regency level;

4) The protection for the witnesses and victims should involve all parties including the community control.

\section{SUGGESTIONS}

Some suggestions are provided to be considered, which are:

1) Improving the role of government, society and related agencies in order to guarantee the protection for the witnesses and victims;

2) Conducting in-depth reviewing about the Law Number 13 of 2006 on the Protection of the Witnesses and Victims due to the fact that there are various cases involving the witnesses and victims;

3) Establishing the witness protection agencies in the provinces, cities, and regencies to reduce the workload and to accommodate the case reports of the witnesses and victims that have not been reported to the witness and victim protection central agencies.

\section{REFERENCES}

Atmasasmita, R. 2001. Reformasi Hukum, Hak Asasi Manusia dan penegakan hukum [Law Reform, Human Rights and Law Enforcement], Cetakan Pertama, Mandar maju. Bandung.

Kadafi, B., et.al. 2002. Advokat Indonesia Mencari Legitimasi, studi tentang tanggung jawab profesi hukum Indonesia [Indonesian Advocates Seek Legitimacy, study on the responsibilities of the Indonesian legal profession], Cetakan Ketiga Pusat Studi Hukum dan Kebijakan Indonesia. Jakarta.

Mertokusumo, S. 1996. Penemuan Hukum Sebuah Pengantar [An Introduction to the Law Discovery]), Liberty Yogyakarta 
Sinaga, A. C. 2006. Saksi Pelapor, Lembaga Perlindungan Saksi dan Koran [Witnesses, Witness Protection Agencies and Newspapers], ELSAM Jakarta

Sumardjono, M. S. W. 2001. Kebijakan Pertanahan Antara Regulasi dan Implementasi [Land Policy Between Regulation and Implementation], Jakarta

Soekanto, S. 1986. Pengantar Penelitian Hukum [Introduction to Law Research], Cetakan Ketiga UI Pres Jakarta

Sumardjono, M. S. W. 2001. Pedoman Pembuatan Usulan Penelitian Sebuah Panduan Dasar [A Basic Guide for Composing Research Proposal], Cetakan Ketiga, Gramedia Pustaka Utama Jakarta.

Widodo, S. 2006. Perlindungan Saksi, Belum Progresif, Catatan Kritis Terhadap Hasil Pembahasan Perlindungan Saksi dan Korban [Protection for the Witnesses, Unprogressive, Critical Note towards the Discussion Result of the Protection of the Witnesses and Victims]. ELSAM Jakarta.

R. Dworkin, 1986, Laws Empire, Harvard University Press

Law

Law Number 13 of 2006 on the Protection of the Witnesses and Victims 